\title{
Revision adenoidectomy in children: residual vs regrowth?
}

\author{
Hassan A. Elhassan ${ }^{1}$. Gülpembe Bozkurt ${ }^{2}$ (1) . İ. Emrah Emre ${ }^{2}$
}

Received: 7 December 2017 / Accepted: 16 December 2017 / Published online: 21 December 2017

c) Springer-Verlag GmbH Germany, part of Springer Nature 2017

Dear Sir,

The recently published article 'Revision adenoidectomy in children: a population-based cohort study in Taiwan' [1] is to be lauded for highlighting the rate of revision adenoid surgery in a large cohort. The paper also highlights two ongoing issues for adenoidectomy surgery; we wondered if the authors are able to assist with more information?

1. Did the primary adenoid surgery utilize visualization, either direct or indirect?

In children who undergo adenoidectomy with blind curettage, up to $80 \%$ do not have adequate removal of the adenoids $[2,3]$. Patients that underwent endoscopic examination at the end of adenoidectomy $(n=118)$ had a $0.85 \%$ revision adenoidectomy rate over 2 years [4], and where endoscopic examination was not performed $(n=194)$; the revision adenoidectomy rate was 5.6\%. Digital palpation of the nasopharynx does not adequately assess adenoid removal [3]. Visualization is a potential factor associated with revision surgery.

2. Where was the location of the residual adenoid tissue?

In patients that undergo blind curettage adenoidectomy, residual adenoid tissue is found in specific locations $-10-80 \%$ in the nasopharyngeal roof, $11-47 \%$ on either side of the nasopharynx, adjacent to the torus tubarius,

This comment refers to the article available at https://doi. org/10.1007/s00405-017-4655-z.

Gülpembe Bozkurt

gptalayhan@gmail.com

Lewisham University Hospital, London, UK

2 Department of Otolaryngology-Head and Neck Surgery, Acıbadem University Faculty of Medicine, Halkalı Merkez Mahallesi, Turgut Özal Bulvarı No:16, Küęükçekmece, 34303 Istanbul, Turkey and in about $6 \%$ at both sites $[3,4]$. Persistent symptoms post-adenoidectomy are more likely due to residual tissue hypertrophy, in the characteristic locations, over time. Currently, there is no high-level evidence for adenoid tissue, once removed, to form anew in the paediatric nasopharnyx. To reduce residual adenoid tissue, direct or indirect visualization using an endoscope or dental mirror is necessary. Endoscopic adenoidectomy allows the removal of peritubaric tissue whilst reducing risk of damage to the Eustachian tube.

Only one study has objectively measured the difference between 'residual' and 'regrowth' adenoid tissue [5]. The terms should not be used interchangeably, as the former is likely related to surgical technique and the latter is construed as spontaneous.

\section{Compliance with ethical standards}

Conflict of interest All the authors declare that they have no conflict of interest.

Ethical approval This article does not contain any studies with human participants or animals performed by any of the authors.

\section{References}

1. Lee CH, Chang WH, Ko JY, Yeh TH, Hsu WC, Kang KT (2017) Revision adenoidectomy in children: a population-based cohort study in Taiwan. Eur Arch Otorhinolaryngol 274:3627-3635

2. Saxby AJ, Chappel CA (2009) Residual adenoid tissue post-curettage: role of nasopharyngoscopy in adenoidectomy. ANZ J Surg 79:809-811

3. Ark N, Kurtaran H, Ugur KS, Yilmaz T, Ozboduroglu AA, Mutlu C (2010) Comparison of adenoidectomy methods: examining with digital palpation vs. visualizing the placement of the curette. Int J Pediatr Otorhinolaryngol 74:649-651

4. Ezzat WF (2010) Role of endoscopic nasal examination in reduction of nasopharyngeal adenoid recurrence rates. Int J Pediatr Otorhinolaryngol 74:404-406

5. Kim SY, Lee WH, Rhee CS, Lee CH, Kim JW (2013) Regrowth of the adenoids after coblation adenoidectomy: cephalometric analysis. Laryngoscope 123:2567-2572 